\title{
Growth, Photosynthesis, and Physiological Responses of Ornamental Plants to Complementation with Monochromic or Mixed Red-Blue LEDs for Use in Indoor Environments
}

\author{
Pedro García-Caparrós ${ }^{1,+}$, Gabriela Martínez-Ramírez ${ }^{2,+}$, Eva María Almansa ${ }^{1,+}$, \\ Francisco Javier Barbero ${ }^{3,+}$, Rosa María Chica ${ }^{4,+}$ (D) and María Teresa Lao ${ }^{1, *,+(D)}$ \\ 1 Agronomy Department of Superior School Engineering, University of Almeria, CIAIMBITAL, \\ Agrifood Campus of International Excellence ceiA3. Ctra. Sacramento s/n, La Cañada de San Urbano, \\ 04120 Almería, Spain; pedrogar123@hotmail.com (P.G.-C.); almansaeva@gmail.com (E.M.A.) \\ 2 Agronomy Department of University of Chapingo, Ctra. Mexico-Texcoco, \\ Chapingo 56230, Chapingo, Mexico; mtlaoa@yahoo.es \\ 3 Chemistry and Physics Department of Superior School Engineering, University of Almería, CIAIMBITAL, \\ Agrifood Campus of International Excellence ceiA3, Ctra. Sacramento s/n, La Cañada de San Urbano, \\ 04120 Almería, Spain; jbarbero@ual.es \\ 4 Engineering Department of Superior School Engineering, University of Almería, CIAIMBITAL, \\ Agrifood Campus of International Excellence ceiA3, Ctra. Sacramento s/n, La Cañada de San Urbano, \\ 04120 Almería, Spain; rmchica@ual.es \\ * Correspondence: mtlao@ual.es; Tel.: +34-950-015876; Fax: +34-950-015939 \\ + All authors contributed equally to this work.
}

Received: 23 January 2020; Accepted: 14 February 2020; Published: 16 February 2020

\begin{abstract}
Inch (Tradescantia zebrina) and spider (Chlorophytum comosum) plants were grown in a growth chamber for two months in plastic containers to evaluate the effects of different light treatments ( $\mathrm{T}_{\mathrm{O}}$ Tube luminescent Dunn (TLD) lamps or control), $\mathrm{T}_{\mathrm{B}}$ (TLD lamps + blue light emitting diodes (LEDs)), $T_{R}$ (TLD lamps + red LEDs), and $T_{B R}$ (TLD lamps + blue and red LEDs) on biomass, photosynthesis, and physiological parameters. Total dry weight and water content were evaluated at the end of the experimental period. After two months, pigment concentrations and the photosynthetic rate were assessed in both species. The total soluble sugar, starch, and proline concentrations in the leaf as physiological parameters were studied at the end of the experiment. Both species had increased root, shoot, and total dry weight under blue LEDs conditions. The chlorophyll concentration showed a specific response in each species under monochromic or mixed red-blue LEDs. The highest photosynthetic rate was measured under the addition of mixed red-blue LEDs with TLD lamps. At the physiological level, each species triggered different responses with respect to total soluble sugars and the proline concentration in leaves under monochromic or mixed red-blue LEDs. Our study demonstrated that the addition of blue LEDs is advisable for the production of these ornamental foliage species.
\end{abstract}

Keywords: biomass; chlorophyll; fluorescent lamp; light treatments; proline; starch

\section{Introduction}

Foliage plant production represents an important agricultural industry worldwide with a net wholesale value of 50 billion $€[1,2]$. Nowadays, the use of foliage plants for removing indoor air pollutants in buildings is a fashion trend among consumers since these species are air-filters for volatile compounds such as benzene [3]. 
The production of indoor foliage plants with an additional capacity of pollutant removal is an added value that should be considered in ornamental horticulture. The choice of species with a well-known capacity to remove pollutants should be done following the recommendations given by Cathey and Campbell [4], who established the lighting requirements for indoor foliage plants. For instance, Chlorophytum comosum is well known to removal volatile compounds such as benzene [5], and Tradescantia sp. removes formaldehyde [6].

In ornamental indoor horticulture, the use of artificial lighting has been related to the improvement of the commercial value which depends on the visual quality characterized by different factors such as stem elongation, compactness, branching, and flowering [7]. Nowadays, light emitting diodes (LEDs) are the most frequently used lighting sources for plant growth under controlled conditions due to their durability, long lifetime, high radiant efficiency, and relatively narrow emission spectra [8,9]. Moreover, LEDs also provide options to select specific wavelengths for a targeted plant response which can be desirable for the production of indoor ornamental plants [10].

We investigated the responses of two different ornamental foliage plants to different light treatments. Tradescantia zebrina (inch plant) is an ornamental foliage plant native to eastern Mexico belonging to the family Commelinaceae. It is prized among interiorscapers for its attractive variegated foliage and tolerance to a wide range of growing conditions [11]. Chlorophytum comosum (spider plant) is an evergreen horticultural plant native to southern Africa belonging to the family Asparagaceae. It is characterized by high biomass production, easy cultivation, intense competitive ability, and wide geographic distribution [12].

There are several studies focused on the effects of mixed lights of fluorescent lamps and LEDs on horticultural crops such as radish and spinach [13], as well as ornamental plants such as marigold and salvia [14]. Nevertheless, there is little information concerning the effects of these mixtures of lights on our targeted foliage species. Therefore, in this trial, a pot experiment with inch and spider plants was established in order to determine the effects of different light treatments on their biomass, photosynthesis, and physiological parameters.

\section{Materials and Methods}

\subsection{Plant Material and Pre-Cultivation}

Rooted inch and spider cuttings (plants) were obtained from plants growing in a multitunnel greenhouse at Almería (lat. $36^{\circ} 49^{\prime} \mathrm{N}$, long. $2^{\circ} 24^{\prime} \mathrm{W}$ ) and were transplanted into $2.0 \mathrm{~L}$ polyethylene pots containing a mixture of sphagnum peat-moss, vegetable compost, and perlite (Natura Universal substrate, Projar, Valencia, Spain). The cuttings of each species were rooted under tunnel propagation for one month (from January to February) with the following microclimatic conditions: ranges of temperatures from 25 to $30{ }^{\circ} \mathrm{C}$ and relative humidity higher than $90 \%$ monitored continuously with a data logger (HOBO model H 08-004-02, Onset Computer Corp., Bourne, MA) under a natural photoperiod (11/13 h light/dark). Both species were watered every two days during the rooting period with a $60 \%$ Steiner nutrient solution. Then, rooted cuttings (plants) were scheduled for follow-up in a growth chamber of $1.5 \times 2.5 \times 2.5=9.38 \mathrm{~m}^{3}$ divided into four compartments $\left(2.16 \mathrm{~m}^{3}\right)$ with a black polyethylene film to prevent interference between neighboring light treatments. Each compartment was assigned to each light treatment during the entire experiment (two months). In each compartment, there were four blocks with six plants per block and species that were randomly positioned. The rooted cuttings of inch plants had an average dry weight of $1.34 \mathrm{~g}$, and spider plants of $0.28 \mathrm{~g}$ on the day of transfer to the growth chamber. The growth chamber was set at a constant (day/night) temperature of $25^{\circ} \mathrm{C}$ and a relative humidity of $55 \%$ to minimize any potentially confounding effect of a diurnal temperature difference or relative humidity on extension growth. To further minimize any edge or position effects within each treatment, the pots were separated with covers and rearranged every other day. During the experimental period, both species were watered manually every day with a Steiner 
nutrient solution in order to avoid any water or nutrient limitation. The plants were grown under a 12/12 $\mathrm{h}$ light/dark photoperiod according to the light requirement of these species [15].

\subsection{Experimental Set-Up and Light Quality Treatments}

The experiment consisted of four light treatments: $T_{O}$ (Tube luminescent Dunn (TLD) lamps) (control treatment) (fluorescent TLD 18W (4 light Philips TCS097 $\times 2$ lamps, Philips Lighting Spain, Madrid, Spain) with a power of $144 \mathrm{~W}$ ), $\mathrm{T}_{\mathrm{B}}$ (TLD lamps + blue LEDs) (fluorescent TLD 18W (4 light Philips TCS097 $\times 2$ lamps, Philips Lighting Spain, Madrid, Spain) and 4 lines of ALUM $40^{*} 25$ blue LEDs $\times 9 \mathrm{~W}$ with console DN-RGB FIBER LIGHT, Modular Signs, Murcia, Spain) with a total power of $180 \mathrm{~W}, \mathrm{~T}_{\mathrm{R}}$ (TLD lamps + red LEDs) (fluorescent TLD 18W (4 light Philips TCS097 $\times 2$ lamps, Philips Lighting Spain, Madrid, Spain) and 4 lines of ALUM $40 * 25$ red LEDs $\times 9 \mathrm{~W}$ with console DN-RGB FIBER LIGHT, Modular Signs, Murcia, Spain) with a total power of $180 \mathrm{~W}$, and $\mathrm{T}_{\mathrm{BR}}$ (TLD lamps + blue and red LEDs) (fluorescent TLD 18W (4 light Philips TCS097 $\times 2$ lamps, Philips Lighting Spain, Madrid, Spain) and 2 lines of ALUM 40*25 red LEDs $\times 9 \mathrm{~W}$ and 2 lines of ALUM $40^{*} 25$ blue LEDs $\times 9 \mathrm{~W}$ with console DN-RGB FIBER LIGHT, Modular Signs, Murcia, Spain) with a total power of $180 \mathrm{~W}$. The spectral distribution scans were recorded at 400-1100 nm with 1-nm steps of the different light treatments with a calibrated spectroradiometer (LI-COR 1800, Lincoln, Ne, USA) at the canopy level. With these measurements, agronomic characterization of each light treatment was assessed following the methodology established by Baille et al. [16]. The experimental design consisted of four light treatments, four random blocks, and six plants (one plant per pot) per block giving a total of 96 plants per species plus border plants per experiment. The selection of these light treatments was done following the recommendations given by local ornamental growers.

\subsection{Biomass Parameters}

At the end of the experimental period, six plants per species and treatment were harvested, the substrate was gently washed from the roots, and the root surface was dried with blotting paper. The plants were divided into roots $(\mathrm{R})$ and shoots $(\mathrm{S})$, and the respective fresh weights (FW) were measured. Roots and shoots were then oven-dried at $60^{\circ} \mathrm{C}$ until they reached a constant weight to provide the respective dry weights (DW). The fresh and dry weights of roots and shoots were used to calculate the water content (WC-g water per $\mathrm{g}$ fresh weight) of each organ as indicated by Ben Amor et al. [17].

\subsection{Photosynthetic Parameters}

To determine the concentrations of pigments (chlorophylls and carotenoids) in leaves, six plants of each species were randomly selected per treatment at harvest. Extraction of chlorophyll a and b (Chl $a$ and $\mathrm{Chl} b$ ) and carotenoids was performed by submerging $0.2 \mathrm{~g}$ of fresh leaves in methanol $(10 \mathrm{~mL})$ in the dark at room temperature $\left(15^{\circ} \mathrm{C}\right)$ for $24 \mathrm{~h}$. The supernatant was removed, and the photosynthetic pigment concentrations were determined colorimetrically at their respective wavelengths using a Shimadzu ultraviolet-1201 spectrophotometer (Shimadzu Scientific Instruments, Columbia, MD): Chl $a(\lambda=666 \mathrm{~nm}), \mathrm{Chl} b(\lambda=653 \mathrm{~nm})$, and carotenoids $(\lambda=470 \mathrm{~nm})$ following the methodology of Wellburn [18]. Pigment concentrations were expressed as $\mathrm{mg}^{-\mathrm{g}^{-1}} \mathrm{FW}$. The leaf photosynthetic rate of each species was measured at the end of the experiment under the compartments used to assess the different light treatments using a leaf portable chamber photosynthesis meter (LC Pro, ADC Bioscientific, Hoddesdon, UK) (leaf temperature $25^{\circ} \mathrm{C}$, RH of $55 \%$, PPFD corresponding to the photosynthetically active radiation (PAR) in each case $\left(107.49,113.33,111.64\right.$, and $117.17 \mathrm{~b}$ for $\mathrm{T}_{0}, \mathrm{~T}_{\mathrm{B}}$, $\mathrm{T}_{\mathrm{R}}$, and $\mathrm{T}_{\mathrm{BR}}$; respectively) and ambient $\mathrm{CO}_{2}$ concentration). The values presented are the mean of 10 measurements and are expressed as $\mu \mathrm{mol} \mathrm{CO} \cdot \mathrm{m}^{-2} \cdot \mathrm{s}^{-1}$. 


\subsection{Physiological Parameters}

To determine the concentrations of total soluble sugars (TSS), starch, and proline in leaves, six plants of each species were randomly selected per treatment at harvest. The free proline, TSS, and starch were determined in an alcoholic extract (supernatant). The free proline concentration was determined by the ninhydrin reagent method. Free proline concentration was expressed as $\mu \mathrm{g} \cdot \mathrm{g}^{-1} \mathrm{FW}$. The total soluble sugar concentration was determined by the anthrone reagent method. The starch concentration was determined using the oven-dried residue from the total soluble sugar determination. The total soluble sugar and starch concentrations were expressed as mg glucose equivalent. ${ }^{-1} \mathrm{FW}$ [19].

\subsection{Statistical Analysis}

The experiment had a completely randomized block design, and the values obtained for each plant and each variable were considered independent replicates. The data were analyzed through one-way analysis of variance (ANOVA) and least significant difference (LSD) tests $(p<0.05)$ in order to assess the differences between treatments. All statistical analyses were done with Statgraphic Plus for Windows (version 5.1; Statpoint Technologies, Warrenton, VA).

\section{Results}

\subsection{Spectral Distribution}

To evaluate the effectiveness of different light regimes, we used the spectral distribution highlighting the different peaks found and compared the integrated photon flux of each agronomic region of interest and its ratios. The spectral distribution of the different light treatments showed common peaks at 404, 436, 486, 544, 580, 612, and $704 \mathrm{~nm}$ (Figure 1). The agronomic characterization of light treatments (Table 1) showed different trends according to the spectral region studied. The values of PAR were slightly higher under the LED-supplemented conditions. The $\mathrm{T}_{\mathrm{BR}}$ treatment had the highest values of PAR and total radiation. The $T_{B}$ and $T_{B R}$ treatments had the highest value in the blue (B) region. Similarly, $T_{R}$ and $T_{B R}$ had the highest value in the red (R) region. All treatments presented the same values of far red radiation (FR) and near infrared radiation (NIR). As far as the ratios was concerned, there were no differences in the ratio PAR:TOTAL between light treatments, i.e., all light treatments had the same light efficiency for agricultural production. The $T_{B}$ treatment had the highest value for the ratio $B: R$, and $T_{B R}$ had the highest PAR:NIR value. Therefore, the $T_{B R}$ treatment should cause less damage to the foliage due to the high temperature. The ratio B:FR had the highest values in $T_{B}$ and $T_{B R}$, whereas the ratio R:FR had the highest values in $T_{R}$ and $T_{B R}$.

Table 1. Agronomic characterization of light treatments ( $T_{O}$ (TLD lamps), $T_{B}$ (TLD lamps + blue LEDs), $\mathrm{T}_{\mathrm{R}}$ (TLD lamps + red LEDs), and $\mathrm{T}_{\mathrm{BR}}$ (TLD lamps + blue and red LEDs)).

\begin{tabular}{|c|c|c|c|c|}
\hline \multirow{2}{*}{ Spectral Region (nm) } & \multicolumn{4}{|c|}{ Photon Flux $\left(\mu \mathrm{mol} \mathrm{m} \mathrm{m}^{-2} \mathrm{~s}^{-1}\right)$} \\
\hline & $\mathbf{T}_{0}$ & $\mathbf{T}_{\mathbf{B}}$ & $\mathbf{T}_{\mathbf{R}}$ & $\mathbf{T}_{\mathrm{BR}}$ \\
\hline UV (300-400) & 0.82 & 0.86 & 0.86 & 0.86 \\
\hline B (400-500) & 27.88 & 33.45 & 27.88 & 33.27 \\
\hline$R(600-700)$ & 39.99 & 39.99 & 44.10 & 43.96 \\
\hline FR (700-800) & 2.51 & 2.51 & 2.51 & 2.51 \\
\hline PAR (400-700) & 107.49 & 113.33 & 111.64 & 117.17 \\
\hline NIR (700-1100) & 3.84 & 3.84 & 3.84 & 3.84 \\
\hline TOTAL (300-1100) & 111.92 & 117.81 & 116.12 & 121.61 \\
\hline
\end{tabular}


Table 1. Cont.

\begin{tabular}{|c|c|c|c|c|}
\hline \multirow{2}{*}{ Spectral Region (nm) } & \multicolumn{4}{|c|}{ Photon Flux $\left(\mu \mathrm{mol} \mathrm{m} \mathrm{m}^{-2} \mathrm{~s}^{-1}\right)$} \\
\hline & $\mathbf{T}_{\mathbf{0}}$ & $\mathbf{T}_{\mathbf{B}}$ & $\mathbf{T}_{\mathbf{R}}$ & $\mathbf{T}_{\mathbf{B R}}$ \\
\hline PAR:TOTAL & 0.96 & 0.96 & 0.96 & 0.96 \\
\hline PAR:NIR & 27.94 & 29.37 & 28.97 & 30.43 \\
\hline B:R & 0.70 & 0.84 & 0.63 & 0.76 \\
\hline $\mathrm{B}: \mathrm{FR}$ & 11.08 & 13.28 & 11.08 & 13.23 \\
\hline R:FR & 15.89 & 15.86 & 17.52 & 17.47 \\
\hline
\end{tabular}

$\mathrm{UV}=$ ultraviolet, $\mathrm{B}=$ blue, $\mathrm{G}=$ green, $\mathrm{R}=$ red, $\mathrm{FR}=$ far red, $\mathrm{PAR}=$ photosynthetically active radiation, $\mathrm{NIR}=$ near infrared radiation.
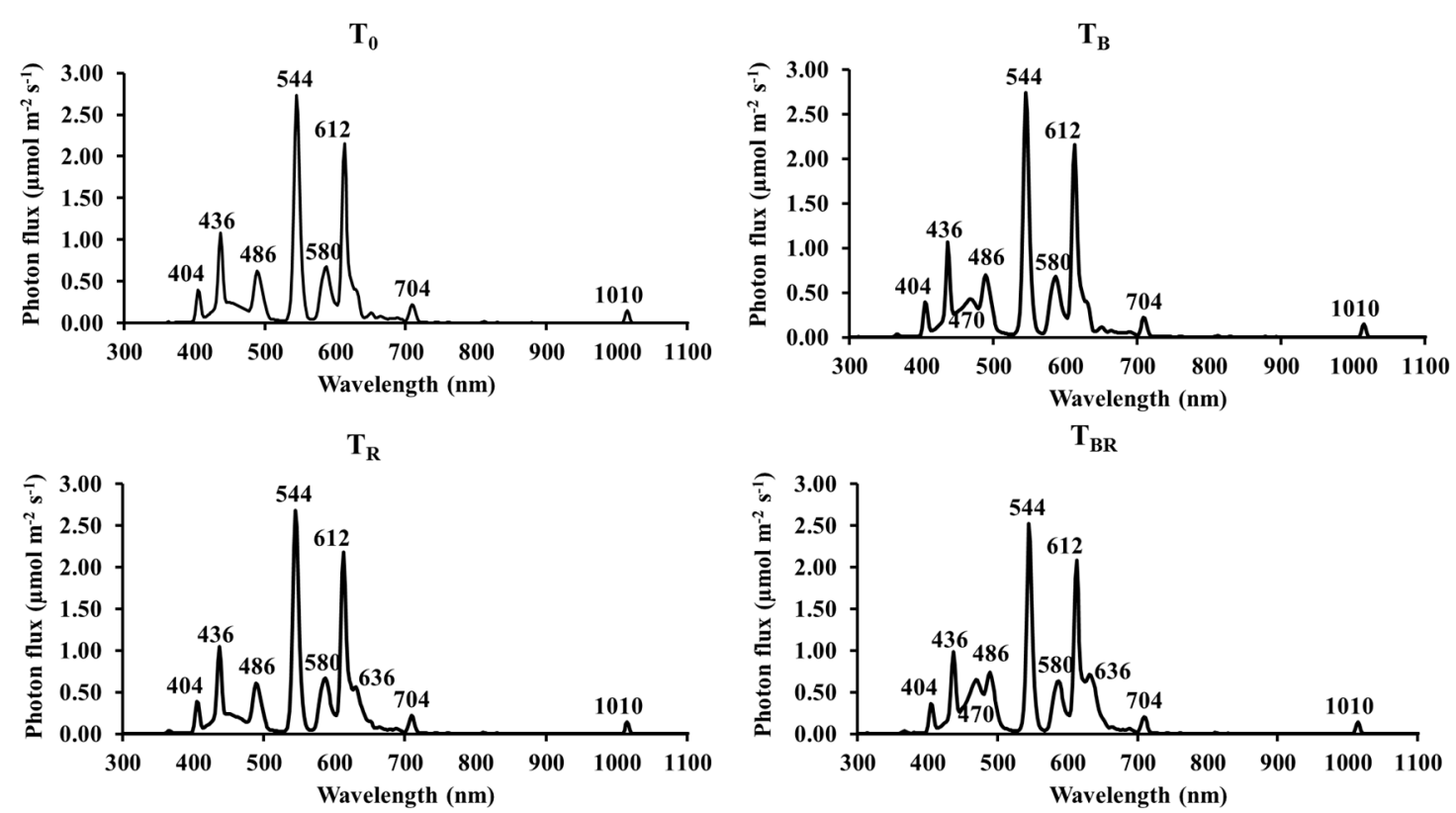

Figure 1. Spectral distribution of the different light treatments with the highlighted peaks presented by the treatments. $T_{O}$ (TLD lamps), $T_{B}$ (TLD lamps + blue LEDs), $T_{R}$ (TLD lamps + red LEDs), and $T_{B R}$ (TLD lamps + blue and red LEDs).

\subsection{Biomass Parameters}

Throughout the experiment, there were no mortalities or any visual damage evident on the plants in response to the different light treatments. In both species, root, stem, and total dry weights had the highest value under $T_{B}$. The water content in the roots and shoots remained unchanged in both species under different light treatments (Table 2).

\subsection{Photosynthetic Parameters}

Chlorophyll $a$ concentrations of inch and spider plant leaves in all treatments were higher than the respective chl $b$ concentrations. In inch plants, the highest chl $a$ and $a+b$ concentration was found in plants grown under $T_{B}$ whereas the control treatment $\left(\mathrm{T}_{0}\right)$ had the highest chl $b$ concentration. In spider plants, the highest $\operatorname{chl} a$ and $a+b$ concentration was found in plants grown under the control treatment whereas growth under $\mathrm{T}_{\mathrm{BR}}$ resulted in the highest chl $b$ concentration. No significant differences were observed in the carotenoid concentration regardless of the light treatment in both species. The photosynthetic rate had the highest value in plants of both species grown under $T_{B R}$ (Table 3). 
Table 2. Effects of different light treatments $\left(T_{O}, T_{B}, T_{R}\right.$ and $\left.T_{B R}\right)$ on the root (RDW), shoot (SDW), and total plant dry weight (TDW), as well as the water content in roots (WCr) and shoots (WCs) in inch (I) and spider plants (S) at the end of the experiment (2 months). Values with the same letters are not significantly different at $p<0.05$ (ANOVA and LSD test). ns: not significant. Data are the means \pm standard deviation of six plants per treatment.

\begin{tabular}{ccccccc}
\hline \multicolumn{2}{c}{ Treatments } & RDW (g) & SDW (g) & TDW (g) & WCr (-) & WCs (-) \\
\hline $\mathrm{I}$ & $\mathrm{T}_{\mathrm{O}}$ & $0.13 \pm 0.01 \mathrm{~b}$ & $3.08 \pm 0.25 \mathrm{~b}$ & $3.21 \pm 0.20 \mathrm{~b}$ & $3.45 \pm 0.25 \mathrm{a}$ & $4.05 \pm 0.36 \mathrm{a}$ \\
& $\mathrm{T}_{\mathrm{B}}$ & $0.19 \pm 0.02 \mathrm{a}$ & $3.93 \pm 0.34 \mathrm{a}$ & $4.10 \pm 0.35 \mathrm{a}$ & $3.39 \pm 0.23 \mathrm{a}$ & $4.07 \pm 0.37 \mathrm{a}$ \\
& $\mathrm{T}_{\mathrm{R}}$ & $0.14 \pm 0.01 \mathrm{~b}$ & $2.93 \pm 0.21 \mathrm{~b}$ & $3.08 \pm 0.22 \mathrm{~b}$ & $3.61 \pm 0.26 \mathrm{a}$ & $3.95 \pm 0.33 \mathrm{a}$ \\
& $\mathrm{T}_{\mathrm{BR}}$ & $0.10 \pm 0.01 \mathrm{c}$ & $3.05 \pm 0.28 \mathrm{~b}$ & $3.16 \pm 0.27 \mathrm{~b}$ & $3.59 \pm 0.25 \mathrm{a}$ & $3.99 \pm 0.33 \mathrm{a}$ \\
\hline $\mathrm{S}$ & $\mathrm{T}_{\mathrm{O}}$ & $0.18 \pm 0.02 \mathrm{~b}$ & $0.88 \pm 0.08 \mathrm{~b}$ & $1.06 \pm 0.10 \mathrm{~b}$ & $6.49 \pm 0.51 \mathrm{a}$ & $2.85 \pm 0.26 \mathrm{a}$ \\
& $\mathrm{T}_{\mathrm{B}}$ & $0.25 \pm 0.02 \mathrm{a}$ & $1.33 \pm 0.13 \mathrm{a}$ & $1.58 \pm 0.15 \mathrm{a}$ & $6.56 \pm 0.53 \mathrm{a}$ & $2.89 \pm 0.27 \mathrm{a}$ \\
& $\mathrm{T}_{\mathrm{R}}$ & $0.15 \pm 0.02 \mathrm{~b}$ & $0.90 \pm 0.08 \mathrm{~b}$ & $1.08 \pm 0.11 \mathrm{~b}$ & $6.41 \pm 0.54 \mathrm{a}$ & $2.91 \pm 0.26 \mathrm{a}$ \\
& $\mathrm{T}_{\mathrm{BR}}$ & $0.10 \pm 0.01 \mathrm{c}$ & $0.71 \pm 0.07 \mathrm{c}$ & $0.81 \pm 0.08 \mathrm{c}$ & $6.59 \pm 0.55 \mathrm{a}$ & $2.96 \pm 0.24 \mathrm{a}$ \\
\hline
\end{tabular}

Table 3. Effects of different light treatments $\left(T_{O}, T_{B}, T_{R}\right.$ and $\left.T_{B R}\right)$ on pigment concentrations and the photosynthetic rate (Pr) of inch (I) and spider plants (S) at the end of the experiment (2 months). Values with the same letters are not significantly different at $p<0.05$ (ANOVA and LSD test). ns: not significant. Data are the means \pm standard deviation of six plants per treatment.

\begin{tabular}{|c|c|c|c|c|c|c|}
\hline \multicolumn{2}{|c|}{ Treatments } & $\begin{array}{c}\text { Chl } a \\
\left(\mathrm{mg} \mathrm{g}^{-1} \mathrm{FW}\right)\end{array}$ & $\begin{array}{c}\mathrm{Chl} b \\
\left(\mathrm{mg} \mathrm{g}^{-1} \mathrm{FW}\right)\end{array}$ & $\begin{array}{c}\text { Chl }(a+b) \\
\left(\mathrm{mg} \mathrm{g}^{-1} \mathrm{FW}\right)\end{array}$ & $\begin{array}{c}\text { Car } \\
\left(\mathrm{mg} \mathrm{g}^{-1} \mathrm{FW}\right)\end{array}$ & $\begin{array}{c}\operatorname{Pr} \\
\mu \mathrm{mol} \mathrm{CO} \mathrm{CO}_{2} \cdot \mathrm{m}^{-2} \cdot \mathrm{s}^{-1}\end{array}$ \\
\hline \multirow[t]{4}{*}{ I } & $\mathrm{T}_{\mathrm{O}}$ & $0.22 \pm 0.02 c$ & $0.08 \pm 0.01 \mathrm{a}$ & $0.31 \pm 0.03 b$ & $0.016 \pm 0.002 \mathrm{a}$ & $0.31 \pm 0.03 b$ \\
\hline & $\mathrm{T}_{\mathrm{B}}$ & $0.39 \pm 0.03 a$ & $0.02 \pm 0.01 b$ & $0.42 \pm 0.03 \mathrm{a}$ & $0.015 \pm 0.002 \mathrm{a}$ & $0.25 \pm 0.02 c$ \\
\hline & $\mathrm{T}_{\mathrm{R}}$ & $0.30 \pm 0.03 b$ & $0.03 \pm 0.01 b$ & $0.32 \pm 0.03 b$ & $0.016 \pm 0.002 \mathrm{a}$ & $0.31 \pm 0.03 b$ \\
\hline & $\mathrm{T}_{\mathrm{BR}}$ & $0.32 \pm 0.03 b$ & $0.03 \pm 0.01 b$ & $0.34 \pm 0.03 b$ & $0.017 \pm 0.003 \mathrm{a}$ & $0.52 \pm 0.05 a$ \\
\hline \multirow[t]{4}{*}{$S$} & $\mathrm{~T}_{\mathrm{O}}$ & $0.44 \pm 0.04 \mathrm{a}$ & $0.02 \pm 0.01 c$ & $0.47 \pm 0.04 a$ & $0.019 \pm 0.002 \mathrm{a}$ & $0.31 \pm 0.03 c$ \\
\hline & $\mathrm{T}_{\mathrm{B}}$ & $0.32 \pm 0.03 b$ & $0.05 \pm 0.01 b$ & $0.37 \pm 0.04 b$ & $0.020 \pm 0.002 \mathrm{a}$ & $0.23 \pm 0.02 \mathrm{~d}$ \\
\hline & $\mathrm{T}_{\mathrm{R}}$ & $0.28 \pm 0.03 b$ & $0.06 \pm 0.01 b$ & $0.34 \pm 0.03 b$ & $0.020 \pm 0.002 \mathrm{a}$ & $0.46 \pm 0.05 b$ \\
\hline & $\mathrm{T}_{\mathrm{BR}}$ & $0.15 \pm 0.02 c$ & $0.11 \pm 0.01 \mathrm{a}$ & $0.26 \pm 0.02 c$ & $0.020 \pm 0.002 \mathrm{a}$ & $0.89 \pm 0.08 \mathrm{a}$ \\
\hline
\end{tabular}

\subsection{Physiological Parameters}

In inch plants, the highest concentration of total soluble sugars and proline in leaves was found in plants grown under $\mathrm{T}_{\mathrm{BR}}$ and $\mathrm{T}_{\mathrm{B}}$, respectively. In spider plants, the control treatment $\left(\mathrm{T}_{0}\right)$ had the highest value of leaf total soluble sugars whereas the highest leaf proline concentration was found in plants grown under $\mathrm{T}_{\mathrm{BR}}$. There were no significant differences in starch concentration at the end of the experiment in inch plants but in spider plants, the highest concentration was found under $T_{B R}$ (Table 4).

Table 4. Effects of light treatments $\left(\mathrm{T}_{\mathrm{O}}, \mathrm{T}_{\mathrm{B}}, \mathrm{T}_{\mathrm{R}}\right.$ and $\left.\mathrm{T}_{\mathrm{BR}}\right)$ on physiological parameters in inch (I) and spider plants $(\mathrm{S})$ at the end of the experiment (2 months). Values with the same letters are not significantly different at $p<0.05$ (ANOVA and LSD test). ns: not significant. Data are the means \pm standard deviation of six plants per treatment.

\begin{tabular}{|c|c|c|c|c|}
\hline \multicolumn{2}{|c|}{ Treatments } & \multirow{2}{*}{$\begin{array}{c}\text { TSS } \\
{\text { mg glucose } \cdot \mathbf{g}^{-\mathbf{1}} \mathbf{F W}}^{3.27 \pm 0.31 \mathrm{~b}}\end{array}$} & \multirow{2}{*}{$\begin{array}{c}\begin{array}{c}\text { Starch } \\
\text { mg glucose }^{-\mathbf{1}} \mathbf{~ F W}\end{array} \\
0.028 \pm 0.002 \mathrm{a}\end{array}$} & \multirow{2}{*}{$\begin{array}{c}\text { Proline } \\
\boldsymbol{\mu g}_{\text {proline.g }} \mathbf{p}^{\mathbf{1}} \mathbf{F W} \\
26.23 \pm 2.56 \mathrm{~b}\end{array}$} \\
\hline I & $\mathrm{T}_{\mathrm{O}}$ & & & \\
\hline & $\mathrm{T}_{\mathrm{B}}$ & $2.41 \pm 0.21 \mathrm{c}$ & $0.027 \pm 0.02 \mathrm{a}$ & $41.72 \pm 4.06 \mathrm{a}$ \\
\hline & $\mathrm{T}_{\mathrm{R}}$ & $2.51 \pm 0.22 c$ & $0.028 \pm 0.02 \mathrm{a}$ & $26.30 \pm 2.61 \mathrm{~b}$ \\
\hline & $\mathrm{T}_{\mathrm{BR}}$ & $4.91 \pm 0.45 \mathrm{a}$ & $0.027 \pm 0.03 a$ & $25.93 \pm 2.13 b$ \\
\hline
\end{tabular}


Table 4. Cont.

\begin{tabular}{|c|c|c|c|c|}
\hline \multicolumn{2}{|c|}{ Treatments } & $\begin{array}{c}\text { TSS } \\
\text { mg glucose } \cdot g^{-1} \text { FW }\end{array}$ & $\begin{array}{c}\text { Starch } \\
\text { mg glucose } \cdot g^{-1} \text { FW }\end{array}$ & $\begin{array}{c}\text { Proline } \\
\mu \mathrm{g} \text { proline } \cdot \mathrm{g}^{-1} \mathrm{FW}\end{array}$ \\
\hline \multirow[t]{4}{*}{$S$} & $\mathrm{~T}_{\mathrm{O}}$ & $20.15 \pm 1.91 \mathrm{a}$ & $0.049 \pm 0.004 b$ & $44.41 \pm 4.24 \mathrm{~d}$ \\
\hline & $\mathrm{T}_{\mathrm{B}}$ & $15.31 \pm 1.33 \mathrm{~b}$ & $0.051 \pm 0.005 b$ & $58.00 \pm 5.16 c$ \\
\hline & $\mathrm{T}_{\mathrm{R}}$ & $15.42 \pm 1.53 b$ & $0.050 \pm 0.005 b$ & $77.72 \pm 7.19 b$ \\
\hline & $\mathrm{T}_{\mathrm{BR}}$ & $15.58 \pm 1.63 b$ & $0.062 \pm 0.005 \mathrm{a}$ & $103.05 \pm 9.74 \mathrm{a}$ \\
\hline
\end{tabular}

\section{Discussion}

The monochromic or mixed red-blue LEDs had different effects on the biomass and biochemical parameters according to the species. After 60 days of exposure, inch and spider plants had the highest root dry weight under the addition of blue LEDs. These results may be related to the fact that under blue light conditions, there is a higher generation of auxins by plants, which improves root growth as reported by Horwitz [20]. In addition, these findings indicate that blue light signals perceived aboveground directly contribute to the regulation of growth and development of roots through the internal light-conducting system from stem to roots as reported by Sun et al. [21]. Nevertheless, the results obtained in this experiment for both species were not in line with the results obtained by Randall and Lopez [22], who carried out an experiment with ornamental plants such as vinca, impatiens, and geraniums under varying proportions (\%) of red:blue light (from 87:13 to 70:30), resulting in a decrease in root dry weight.

The lack of variation in the root dry weight in both species in our experiment under red light conditions was in line with the results obtained by Randall and Lopez [23], who reported that snapdragon, Madagascar periwinkle, zonal geranium, and French marigold plants did not show significant changes in root dry weight under red light conditions compared to the control treatment.

The incorporation of blue LEDs increased the shoot and total dry weights in both species compared to plants grown under only TLD lamps. Contradictory and variable results can be found in the literature concerning the effects of blue light on the biomass in different species. For instance, different researchers have reported an increase in dry weight under blue light conditions in crops such as spinach [24]. Nevertheless, other researchers have reported a reduction in dry weight under blue light in other crops such as red leaf lettuce [25] and Chrysanthemum morifolium [26]. The results obtained in our experiment suggest a strong morphogenetic effect since the addition of blue LEDs to TLD lamps in both species resulted in the production of plants that were more saleable mainly due to the increase in biomass.

In our experiment, the water content in the shoots and roots of both species was not affected by the addition of red, blue or the mixed red and blue LEDs to the control treatment. These results disagree with those reported by Almansa et al. [27], who noted that the addition of red and blue LEDs to fluorescent lamps resulted in a decrease in the water content of tomato seedlings. It is possible that if the experiment was extended for a longer period ( $>60$ days), the water content will probably have been affected.

As far as pigment concentration was concerned, there were different trends between the species. For instance, inch plants had the highest concentrations of Chl $a$ and $\mathrm{Chl}(a+b)$ under blue light conditions, whereas spider plants had the highest values of Chl $a$ and Chl $(a+b)$ in the control treatment without the addition of any type of LED. It is worth mentioning that a high chlorophyll concentration in plants, which causes a dark green coloration of leaves, is a desirable feature, especially in ornamental plants [28]. In the case of inch plants, the highest concentrations of Chl $a$ and $\mathrm{Chl}(a+b)$ under blue LED light may be the result of the positive and synchronized influence of blue light on both nuclear and plastid genomes and could have played a vital role in the formation of chlorophyll and chloroplast development as reported by Akoyunoglou and Anni [29]. Similar results have been reported by other researchers for other crops such as grapes [30] and chrysanthemum [31]. The increase in the chlorophyll concentration under blue light conditions may be also ascribed to the enhancement of the 5 -aminolevulinic acid synthesizing activity, which in turn mediates the biosynthesis of tetrapyrroles 
such as chlorophylls, as reported by Kamiya et al. [32]. With respect to spider plants, the decrease in pigment concentrations in our experiment under monochromic or mixed red-blue LEDs may suggest chlorophyll degradation under changes in irradiance wavelengths as reported by Taiz and Zeiger [33].

In our experiment, the addition of blue, red or mixed red and blue LEDs to TLD lamps did not affect the carotenoid concentration compared to the plants grown under only TLD lamps, for both species. These results suggest that the carotenoid concentration did not appear to be influenced by the wavelengths in the light environment, coinciding with the results reported by Zheng and Van Labeke [7], who noted that carotenoid concentrations in cabbage tree and weeping fig did not vary under different light treatments.

The highest photosynthetic rate reported in both species in our experiment under the combination of blue and red LEDs is in line with the results reported by different researchers for other ornamental species such as Withania somnifera [34], Rosa sp. [35], and Petunia x hybrida [36] grown under a combination of red and blue lights. These results can be related to the fact that plants grown under mixed red and blue LEDs absorb the most efficient wavelengths for photosynthesis [37] since the peaks of B and R LEDs coincide with the peaks of the relative quantum efficiency curve [38].

Light quality may regulate carbohydrate metabolism of plants as well as being involved in other physiological processes [39]. In our present study, we investigated the effect of spectral quality of different LEDs on the total soluble sugar, starch, and proline concentrations in the leaves of two indoor foliage plants. In inch plants, the highest leaf total soluble sugar concentration under mixed red-blue LEDs may be ascribed to the high photosynthetic rate and the compactness of plants due to the ratios R/FR and B/R already explained agreeing with the results reported by Almansa et al. [40]. In the case of spider plants, the lower values of the leaf total soluble sugar concentration under monochromic or mixed red-blue LEDs may be attributed to an accumulation of starch [33]. With respect to starch concentration, the highest concentration reported under mixed red-blue LEDs was related to the high photosynthetic rate. These results are similar to those obtained by Heo et al. [41] in an experiment carried out with different species of bedding plants such as floss flower, Mexican marigold, and scarlet sage under different light treatments. They reported that all the species studied were sensitive to the different mixtures of radiation, and the accumulation of starch in leaves increased under blue and red-light conditions.

Similar to the leaf total soluble sugar concentration, the leaf proline concentration showed a differential response in both species according to the type of LED. For example, the addition of blue LEDs to TLD lamps resulted in the highest leaf proline concentration in inch plants whereas in spider plants, the highest leaf proline concentration was found under the combination of red and blue LEDs with TLD lamps. There are few reports concerning the effects of light quality on the leaf proline concentration. The result of this experiment showed that the increase in the leaf proline concentration in inch plants under the addition of blue LEDs was in line with the results obtained by Zheng and Van Labeke [42] for chrysanthemum plants.

\section{Conclusions}

The addition of monochromic or mixed red-blue LEDs triggered different responses in each species. At the end of the experimental period, the highest root, shoot, and total dry weights were found in both species grown under the blue LEDs with TLD lamps. There were different responses at the photosynthetic and physiological levels in both species under the different light regimes. Under mixed-red blue conditions, there was a higher accumulation of carbohydrates as total soluble sugars in inch plants and as starch in spider plants. These results suggest the importance of studying the effects of different light conditions to establish the light requirements of these two foliage species in indoor environments. The addition of blue LEDs to TLD lamps improved the biomass of both species, resulting in more saleable plants to growers and gardeners.

Author Contributions: P.G.-C., investigation, data curation, writing-original draft preparation. G.M.-R., investigation, data curation. E.M.A., formal analysis, investigation. F.J.B., formal analysis, investigation. R.M.C., 
analysis, investigation. M.T.L., conceptualization, supervision, project administration. All authors have read and agreed to the published version of the manuscript.

Acknowledgments: The authors thank Professor Mohammadreza Sabzalian for his suggestions and English style corrections. The authors also thank the AGR-242 group from the University of Almería (Sustainability of Horticultural and Ornamental Protected Systems) for funding.

Conflicts of Interest: The authors declare no conflict of interest

\section{References}

1. Lütken, H.; Clarke, J.L.; Müller, R. Genetic engineering and sustainable production of ornamentals: Current status and future directions. Plant Cell Rpt. 2012, 31, 1141-1157. [CrossRef] [PubMed]

2. García-Caparrós, P.; Llanderal, A.; Pestana, M.; Correia, P.J.; Lao, M.T. Tolerance mechanisms of three potted ornamental plants grown under moderate salinity. Sci. Hortic. 2016, 201, 84-91. [CrossRef]

3. Panyametheekul, S.; Rattanapun, T.; Morris, J.; Ongwandee, M. Foliage houseplant responses to low formaldehyde levels. Build. Environ. 2019, 147, 67-76. [CrossRef]

4. Cathey, H.M.; Campbell, L.E. Indoor Gardening: Artificial Lighting, Terrariums, Hanging Baskets, and Plant Selection; Home and Garden Bulletin; US Department of Agriculture (USA): Washington, DC, USA, 1978.

5. Sriprapat, W.; Suksabye, P.; Areephak, S.; Klantup, P.; Waraha, A.; Sawattan, A.; Thiravetyan, P. Uptake of toluene and ethylbenzene by plants: Removal of volatile indoor air contaminants. Ecotoxicol. Environ. Saf. 2014, 102, 147-151. [CrossRef] [PubMed]

6. Yang, D.S.; Pennisi, S.V.; Son, K.-C.; Kays, S.J. Screening indoor plants for volatile organic pollutant removal efficiency. HortScience 2009, 44, 1377-1381. [CrossRef]

7. Zheng, L.; Van Labeke, M.C. Chrysanthemum morphology, photosynthetic efficiency and antioxidant capacity are differentially modified by light quality. J. Plant. Physiol. 2017, 213, 66-74. [CrossRef]

8. Massa, G.D.; Kim, H.H.; Wheeler, R.M.; Mitchell, C.A. Plant productivity in response to LED lighting. HortScience 2008, 43, 1951-1956. [CrossRef]

9. Morrow, R.C. LED lighting in horticulture. HortScience 2008, 43, 1947-1950. [CrossRef]

10. Hernández, R.; Kubota, C. Physiological responses of cucumber seedlings under different blue and red photon flux ratios using LEDs. Environ. Exp. Bot. 2016, 121, 66-74. [CrossRef]

11. Florindo, J.B.; Landini, G.; Almeida-Filho, H.; Bruno, O.M. Analysis of stomata distribution patterns for quantification of the foliar plasticity of Tradeschantia zebrina. J. Phys. Conf. Ser. 2015, 633, 012113. [CrossRef]

12. Wang, Y.; Tao, J.; Dai, J. Lead tolerance and detoxification mechanism of Chlorophytum comosum. Afr. J. Biotechnol. 2011, 10, 14516-14521.

13. Yorio, N.C.; Goins, G.D.; Kagie, H.R.; Wheeler, R.M.; Sager, J.C. Improving spinach, radish, and lettuce growth under red light-emitting diodes (LED) with blue light supplementation. HortScience 2001, 36, 380-383. [CrossRef] [PubMed]

14. Heo, J.W.; Lee, C.W.; Chakrabarty, D.; Paek, K.Y. Growth responses of marigold and salvia bedding plants as affected by monochromic or mixture radiation provided by a light-emitting diode (LED). Plant Growth Reg. 2002, 38, 225-230. [CrossRef]

15. Jimenez, R.; Caballero, M. El Cultivo Industrial de Plantas en Maceta; Ediciones de Horticultura S.L.: Barcelona, Spain, 1990.

16. Baille, A.; González-Real, M.M.; López, J.C.; Cabrera, J.; Pérez-Parra, J. Characterization of the solar diffuse component under "Parral" plastic greenhouses. Acta Hortic. 2003, 614, 341-346. [CrossRef]

17. Ben Amor, N.; Ben Hamed, K.; Debez, A.; Grignon, C.; Abdelly, C. Physiological and antioxidant responses of the perennial halophyte Crithmum maritimum to salinity. Plant Sci. 2005, 168, 889-899. [CrossRef]

18. Wellburn, A. The spectral determination of chlorophylls a and $b$, as well as total carotenoids, using various solvent with spectrophotometers of different resolution. J. Plant Physiol. 1994, 144, 307-313. [CrossRef]

19. Irigoyen, J.J.; Emerich, D.W.; Sánchez-Díaz, M. Water stress induced changes in concentrations of proline and total soluble sugars in nodulated alfalfa (Medicago sativa) plants. Physiol. Plant. 1992, 84, 55-60. [CrossRef]

20. Horwitz, B.A. Properties and transducers chains of the UV and the Blue light photoreceptors. In Photomorphogenesis in Plants, 2nd ed.; Kendirck, R.E., Kronenberg, G.H.M., Eds.; Kluwer Academic Publishers: Dordrecht, The Netherlands, 1994; pp. 327-350. 
21. Sun, Q.; Yoda, K.; Suzuki, H. Internal axial light conduction in the stems and roots of herbaceous plants. J. Exp. Bot. 2005, 56, 191-203. [CrossRef]

22. Randall, W.C.; Lopez, R.G. Comparison of bedding plant seedlings grown under sole-source light-emitting diodes (LEDs) and greenhouse supplemental lighting from LEDs and high-pressure sodium lamps. HortScience 2015, 50, 705-713. [CrossRef]

23. Randall, W.C.; Lopez, R.G. Comparison of supplemental lighting from high-pressure sodium lamps and light-emitting diodes during bedding plant seedling production. HortScience 2014, 49, 589-595. [CrossRef]

24. Matsuda, R.; Ohashi-Kaneko, K.; Fujiwara, K.; Kurata, K. Effects of blue light deficiency on acclimation of light energy partitioning in PSII and $\mathrm{CO}_{2}$ assimilation capacity to high irradiance in spinach leaves. Plant Cell Physiol. 2008, 49, 664-670. [CrossRef] [PubMed]

25. Johkan, M.; Shoji, K.; Goto, F.; Hashida, S.N.; Yoshihara, T. Blue light-emitting diode light irradiation of seedlings improves seed quality and growth after transplanting in red leaf lettuce. HortScience 2010, 45, 1809-1814. [CrossRef]

26. Jeong, S.W.; Park, S.; Jin, J.S.; Seo, O.N.; Kim, G.S.; Kim, Y.H.; Bae, H.; Lee, G.; Kim, S.T.; Lee, W.S.; et al. Influences of four different light-emitting diode lights on flowering and polyphenol variations in the leaves of Chrysanthemum (Chrysanthemum morifolium). J. Agric. Food Chem. 2012, 60, 793-800. [CrossRef] [PubMed]

27. Almansa, E.M.; Espín, A.; Chica, R.M.; Lao, M.T. Changes in endogenous auxin concentration in cultivars of tomato seedlings under artificial light. HortScience 2011, 46, 698-704. [CrossRef]

28. Reid, M.S.; Jiang, C. Postharvest biology and technology of ornamentals. Hort. Rev. 2012, 40, 1-54.

29. Akoyunoglou, G.; Anni, H. Blue Light Effects in Biological Systems; Springer: Berlin, Germany, 1984; pp. 397-406.

30. Poudel, P.R.; Kataoka, I.; Mochioka, R. Effect of red-and blue-light-emitting diodes on growth and morphogenesis of grapes. Plant. Cell Tissue Org. Cult. 2008, 92, 147-153. [CrossRef]

31. Kurilcik, A.; Miklusyte-Canova, R.; Dapkuniene, S.; Zilinskaite, S.; Kurilcik, G.; Tamulaitis, G.; Duchovskis, P.; Zukauskas, A. In vitro culture of Chrysanthemum plantlets using light-emitting diodes. Central Eur. J. Biol. 2008, 3, 161-167. [CrossRef]

32. Kamiya, A.; Ikegami, I.; Hase, E. Effects of light on chlorophyll formation in cultured tobacco cells II. Blue light effect on 5-aminolevulinic acid formation. Plant Cell Physiol. 1983, 24, 799-809. [CrossRef]

33. Taiz, L.; Zeiger, E. Plant Physiology, 3rd ed.; Sinauer Associates: Sunderland, MA, USA, 2002; 690p.

34. Lee, S.H.; Tewari, R.K.; Hahn, E.J.; Paek, K.Y. Photon flux density and light quality induce changes in growth, stomatal development, photosynthesis and transpiration of Withania somnifera (L.) Dunal. plantlets. Plant. Cell Tissue Org. Cult. 2007, 90, 141-151. [CrossRef]

35. Bergstrand, K.J.; Mortensen, L.M.; Suthaparan, A.; Gislerød, H.R. Acclimatisation of greenhouse crops to differing light quality. Sci. Hortic. 2016, 204, 1-7. [CrossRef]

36. Phansurin, W.; Jamaree, T.; Sakhonwasee, S. Comparison of growth, development, and photosynthesis of petunia grown under white or red-blue led lights. Hortic. Sci. Tech. 2017, 35, 689-699.

37. Terashima, I.; Fujita, T.; Inoue, T.; Chow, W.S.; Oguchi, R. Green light drives leaf photosynthesis more efficiently than red light in strong white light: Revisiting the enigmatic question of why leaves are green. Plant Cell Physiol. 2009, 50, 684-697. [CrossRef] [PubMed]

38. McCree, K.J. The action spectrum, absorbance and quantum yield of photosynthesis in crop plants. Agr. Meteorol. 1972, 9, 191-216. [CrossRef]

39. Kowallik, W. Blue light effect on carbohydrate and protein metabolism. In Blue Light Responses: Phenomena and Occurrence in Plants and Microorganisms; Senger, H., Ed.; CRC Press: Boca Raton, FL, USA, 1987; Volume II, pp. 7-16.

40. Almansa, E.M.; Espín, A.; Chica, R.M.; Lao, M.T. Bioassimilation behaviour of tomato seedling cultivars under different sources of artificial light. Austr. J. Crop. Sci. 2014, 8, 873.

41. Heo, J.W.; Lee, C.W.; Paek, K.Y. Influence of mixed LED radiation on the growth of annual plants. J. Plant Biol. 2006, 49, 286-290. [CrossRef]

42. Zheng, L.; Van Labeke, M.C. Long-term effects of red-and blue-light emitting diodes on leaf anatomy and photosynthetic efficiency of three ornamental pot plants. Front. Plant Sci. 2017, 8, 917. [CrossRef]

(C) 2020 by the authors. Licensee MDPI, Basel, Switzerland. This article is an open access article distributed under the terms and conditions of the Creative Commons Attribution (CC BY) license (http://creativecommons.org/licenses/by/4.0/). 